\title{
Incidence and Distribution of Puccinia coronata and P. graminis on Turfgrass in the Midwestern United States
}

Brijesh B. Karakkat, Vonte L. Jackson, and Paul L. Koch, ${ }^{\dagger}$ Department of Plant Pathology, University of Wisconsin-Madison, Madison 53706

\begin{abstract}
Crown rust (caused by Puccinia coronata) and stem rust (caused by $P$. graminis) are two common and destructive diseases of turfgrass in the United States. Crown rust has been associated with perennial ryegrass and stem rust with Kentucky bluegrass when identified based solely on fungal morphology. However, recent studies using molecular identification methods have indicated the host-pathogen relationship of rusts on turf to be more complex. Our primary objective was to quickly and accurately identify $P$. coronata and $P$. graminis in symptomatic turfgrass leaves over 3 years on turfgrass samples from across the Midwestern United States. Between 2013 and 2015, 413 samples of symptomatic cool-season turfgrass from Wisconsin and surrounding states were screened using real-time polymerase chain

reaction. Of these samples, 396 were Kentucky bluegrass and $17 \%$ of them contained $P$. coronata, $69 \%$ contained $P$. graminis, and $13 \%$ contained both $P$. coronata and $P$. graminis. In addition, both year and location effects were observed on the distribution of Puccinia spp. collected annually from two locations in southern Wisconsin. This research supports previous conclusions that have identified variability among $P$. graminis and $P$. coronata host relationships on turfgrass, and further demonstrates that rust fungal populations on Kentucky bluegrass may not be consistent between locations in the same year or over multiple years at the same location. The increasing evidence of variation in the turfgrass rust populations will likely affect future rust management and turfgrass breeding efforts.
\end{abstract}

Rust diseases caused by Puccinia spp. are among the most economically important diseases of agronomic crops such as wheat (Triticum aestivum), barley (Hordeum vulgare), and oat (Avena sativa) (Bockus et al. 2010). Rusts are also important diseases of amenity turfgrasses grown on home lawns, athletic fields, golf courses, and roadsides around the world (Smiley et al. 2005). Rust symptoms on turfgrass typically appear as orange or yellow-colored foliage that is unsightly and unacceptable to those who use and manage these sites. If left unchecked, rusts can eventually result in stunting and thinning of the turfgrass plants and, in rare cases, death of an entire turfgrass stand (Smiley et al. 2005). Fungicide applications and cultural practices such as increased fertilization can be used to suppress rust outbreaks but host resistance has historically been one of the most common and effective rust control measures on turfgrass (Bonos et al. 2006).

There are 40 different rust diseases that have been identified on turfgrass (Smiley et al. 2005). The two most common rusts on cool-season $\left(\mathrm{C}_{3}\right.$ photosynthesis) turfgrasses are stem rust caused by Puccinia graminis and crown rust caused by $P$. coronata (Beirn et al. 2011). On turfgrass, $P$. graminis has historically been associated exclusively with Kentucky bluegrass (KB) (Poa pratensis) and identified morphologically by the orange- to red-colored urediniospores present on infected leaf blades (Smith et al. 1989). It is a heteroecious macrocyclic fungus that requires infection of an alternate host, the common barberry (Berberis vulgaris), to complete the sexual part of its life cycle. In the absence of barberry, Puccinia graminis reinfects grasses by asexual urediniospores (Stakman et al. 1934). Common barberry was largely eradicated east of the Mississippi River in the early 20 th century to reduce $P$. graminis epidemics on wheat, and it remains relatively rare in the upper Midwest today (Campbell and Long 2001; Leonard and Szabo 2005). Therefore, the majority of

${ }^{\dagger}$ Corresponding author: P. L. Koch; E-mail: plkoch@wisc.edu

Funding: This work was funded by the Wisconsin Specialty Crop Block Grant Program (grant number 2012-003) and the Wisconsin Sod Producers Association.

*The $\boldsymbol{e}$-Xtra logo stands for "electronic extra" and indicates that one supplementary table is published online.

Accepted for publication 7 December 2017.

C 2018 The American Phytopathological Society
P. graminis spores infecting grass species in the upper Midwest are genetically uniform urediniospores that migrate to the region on seasonal wind currents (Kolmer 2005; Leonard and Szabo 2005; Nagarajan and Singh 1990).

$P$. coronata on turfgrass has historically been associated with perennial ryegrass (PR) (Lolium perenne) (Potter 1987) in both pasture and turf settings, and is identified by the yellow- to orange-colored urediniospores found on infected leaf blades (Smith et al. 1989). The fungus also has a crown-like apical structure on the teliospores, a feature that differentiates them from $P$. graminis teliospores; however, teliospores only occur following completion of the full sexual life cycle (Harshberger 1917). Like P. graminis, $P$. coronata is also a heteroecious macrocyclic fungus but requires buckthorn (Rhamnus spp.) as the alternate host to complete its sexual life cycle (Simons 1970). Buckthorn, unlike barberry, is pervasive across the upper Midwest and allows earlier infections and more genetically diverse $P$. coronata populations to infect turfgrass relative to $P$. graminis (Simons 1970). This genetic diversity allows more rapid evolution of $P$. graminis fungal races that may more readily evade plant host defenses (Frey et al. 1973).

$\mathrm{KB}$ is the most popular grass species in lawns and athletic fields throughout temperate regions of the United States, and turfgrass breeders observed increased rust severity on KB early in the 21 st century (Bonos et al. 2006). Rust was particularly severe on the recently released Midnight cultivars, which are popular for their dense growth and dark green color (Bonos et al. 2006). Shortly thereafter, sod producers in Wisconsin and neighboring states reported incidences of rust that were difficult to manage. The authors conducted an online survey of 11 sod producers from Wisconsin and Illinois in 2015 . All 11 of the sod producers identified rust as a problem at their facility at least once in the last 5 years. Nine identified rusts as the most severe disease affecting their facility over the previous 5 years, while six agreed that rust seemed to be getting worse over the previous 5 -year period. In addition, average annual expenditures to control rust among the 11 respondents ranged from $\$ 1,500$ to $\$ 25,000$.

The original hypothesis surrounding the increasing rust severity was that a new race or races of $P$. graminis had emerged that were particularly aggressive on Midnight cultivars of KB (Beirn et al. 2011; Bonos et al. 2006). Beirn et al. (2011) tested this hypothesis by using phylogenetic analyses, real-time polymerase chain reaction (PCR) assays, and morphological characteristics such as urediniospores size, shape, and color to identify 66 turfgrass rust samples predominantly from the northeastern United States. The authors found that fungal 
identification based on host species and urediniospore morphology resulted in an incorrect diagnosis $58 \%$ of the time. Of greater consequence was that $P$. coronata was frequently detected on $\mathrm{KB}$, an association that had not been previously reported. Because $P$. coronata regularly completes its sexual life cycle on the ubiquitous buckthorn, the genetic diversity present within its population may allow more rapid development of races that can infect $\mathrm{KB}$ cultivars and complicate future $\mathrm{KB}$ breeding efforts. Loss of host resistance to rusts in $\mathrm{KB}$ and other turfgrass species may then lead to increased use of supplemental irrigation, synthetic fertilizer, and pesticides that can have detrimental nontarget impacts on human and environmental health (Robbins et al. 2001; Vincelli 2004).

The Beirn et al. (2011) study provided important insights into the increases in rust severity observed on KB in recent years. Our study was designed to take the information gained from the previous study and apply it to a larger sample size in the Midwestern United States over a 3-year period. Our primary objective was to use previously developed real-time PCR assays to screen Puccinia-infected turfgrass plants and determine the incidence, distribution, host specificity, and diversity of $P$. coronata and $P$. graminis on different turfgrass species sampled from Wisconsin and surrounding states.

\section{Materials and Methods}

Sample collection. In total, 413 turfgrass samples exhibiting rust symptoms were collected from Wisconsin and surrounding states or collected by the authors between 2013 and 2015. Sampling time ranged

Table 1. Samples of grass species with rust pathogens from Wisconsin and neighboring states collected from 2013 through 2015

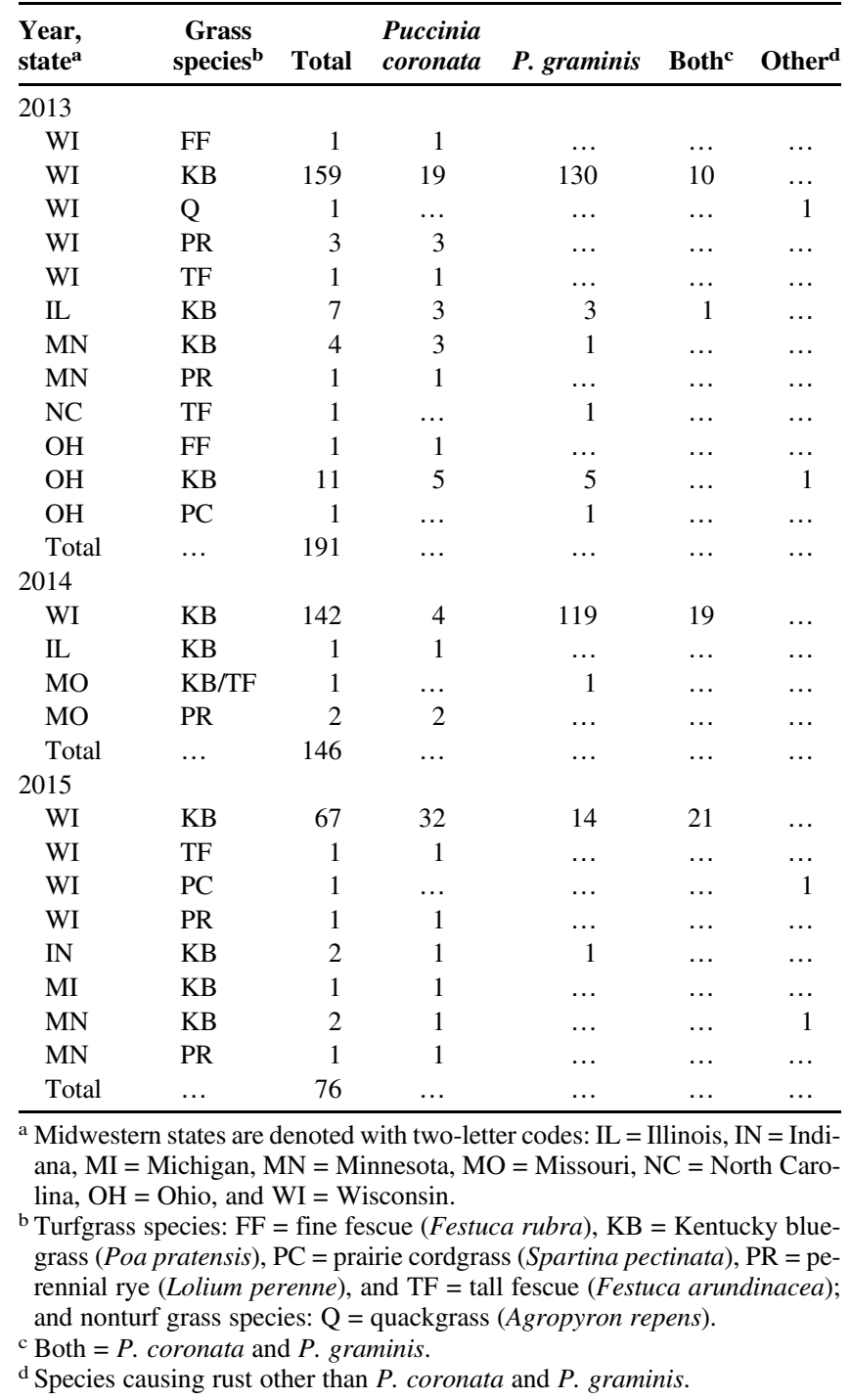

from late summer to early fall within each year. Samples were collected from homeowners, university faculty, sod producers, and managers of athletic fields, golf courses, and roadsides. For each sample, three to six infected leaf blades were immediately wrapped in aluminum foil and stored at $-20^{\circ} \mathrm{C}$ until DNA extraction could be performed.

Of the 413 total samples, 307 were collected from two Wisconsin locations between 2013 and 2015. The first location was the O. J. Noer Turfgrass Research and Education Facility (OJN) in Madison, WI. Two separate plots seeded in 2013 were sampled at the OJN, a National Turfgrass Evaluation Program research plot containing $82 \mathrm{~KB}$ cultivars and a separate $\mathrm{KB}$ rust-resistance cultivar trial containing 30 different cultivars. The second location was a sod farm (SF) in southern Wisconsin containing the same $30 \mathrm{~KB}$ cultivars that were planted at the OJN location. The OJN was sampled once in both 2013 and 2014 and the SF was sampled once in 2013, 2014, and 2015. All samplings were conducted from September through October in each year when rust severity was high. The OJN was not sampled in 2015 because rust signs or symptoms were not observed. One sample was collected from each cultivar exhibiting rust symptoms in the same manner as described previously. Fisher's exact test was used to determine location effect (OJN versus SF) on the $P$. graminis and $P$. coronata distribution in 2013 , and also to determine year effect on $P$. graminis and $P$. coronata distributions at the SF. Analysis was conducted using R (v. 3.2.0) (R Core Team 2015).

Genomic DNA isolation. Total genomic DNA was isolated by modifying Elder et al. (1983). Grass blades infected with fungal spores were diced to $0.5 \mathrm{~cm}$ or less using a razor blade to fill onethird of a $1.5-\mathrm{ml}$ polypropylene DNase/RNase-free microcentrifuge tube (Fisher Scientific, Waltham, MA). They were then suspended in $0.5 \mathrm{ml}$ of lysis buffer containing $0.5 \mathrm{M}$ sodium chloride, $0.01 \mathrm{M}$ EDTA, $0.2 \mathrm{M}$ TRIS- $\mathrm{HCl}$ ( $\mathrm{pH} 8.0$ ), $1 \%$ sodium dodecyl sulfate, and $150 \mathrm{mg}$ of 710 - to $1,180-\mu \mathrm{m}$-sized acid-washed glass beads (Sigma-Aldrich, St. Louis). The solution was vigorously shaken for $2 \mathrm{~min}$ at $6 \mathrm{~m} / \mathrm{s}$ in a benchtop homogenizer (MP Fastprep-24; MP Biomedicals, LLC, Santa Ana, CA) to disrupt fungal spore cell walls and then incubated at $60^{\circ} \mathrm{C}$ in a water bath for $0.5 \mathrm{~h}$. The solution was then incubated with $5 \mu l$ of RNase $(10 \mathrm{mg} / \mathrm{ml})$ at $37^{\circ} \mathrm{C}$ for 15 min to remove RNA. The solution was extracted with phenolchloroform, centrifuged to remove the aqueous phase, placed in a new microcentrifuge tube, precipitated with absolute ethanol, rinsed twice with $70 \%$ ethanol, and air dried. DNA was dissolved in $50 \mu \mathrm{l}$ of Tris-EDTA ( $\mathrm{pH}$ 8.0), quantified by measuring absorbance in a Nanodrop-1000 Spectrophotometer (Thermo Fisher Scientific, Wilmington, MA), and verified by agarose gel electrophoresis.

Real-time PCR primer and probe design. Real-time PCR primers and probes (Table 1) were synthesized by Integrated DNA Technologies (Coralville, IA). Specific conditions such as amplicon size were maintained per Bio-Rad real-time PCR application instructions (http://www.gene-quantification.com/real-time-pcr-guide-bio-rad. pdf). The $P$. coronata probe from Beirn et al. (2011) provided consistent $P$. coronata detection but the remaining primers and probes from Beirn et al. (2011) provided inconsistent detection on our known Puccinia samples. Therefore, we designed new $P$. coronata and $P$. graminis primers using GenBank accession numbers GU598056 (P. coronata) and GU598051 (P. graminis) and a new P. graminis probe (Gra_probe_GU598051). The GU598056 accession was originally isolated from tall fescue (Festuca arundinacea) and the GU598051 accession was isolated from KB (Beirn et al. 2011). The primers were developed to amplify the nuclear ribosomal internal transcribed spacer (ITS)1, 5.8S, and ITS2 regions and the $18 \mathrm{~S}$ and $28 \mathrm{~S}$ partial sequence of ribosomal RNA gene (White et al. 1990) (Table 1). Both PuCR-ITS2 and Gra_probe_GU598051 were labeled with fluorescent reporter dye 6-carboxy-fluorescein (FAM) at the $5^{\prime}$ end and Iowa Black FQ quencher dye at the $3^{\prime}$ end. The ZEN internal quencher was positioned in the middle of the probes for additional specificity (Table 1).

Real-time PCR conditions. All real-time PCR were performed using the CFX96 real-time PCR system (Bio-Rad, Hercules, CA). Assays were performed using $5 \mu$ l of real-time PCR 2 X KAPA probe force universal mastermix (KAPA Biosystem Inc., Wilmington, MA), the two primers $(0.2 \mu \mathrm{M}$ each $)$, the probe $(0.3 \mu \mathrm{M})$, and $2 \mu \mathrm{l}$ of sample 
DNA $(0.1$ to $1 \mathrm{ng} / \mu \mathrm{l})$, then adjusted to a final reaction volume of $10 \mu \mathrm{l}$ with nuclease-free PCR-grade water (Fisher Scientific). The reaction was loaded in Hard-Shell low-profile thin-wall 96-well skirted PCR plates (Bio-Rad) and sealed with microseal B adhesive seals (Bio-Rad). Rust samples collected from the field and positively identified as $P$. graminis and $P$. coronata by teliospore morphology were included as positive controls for the respective real-time PCR probe. The sample DNA, positive DNA control, and water negative control were replicated three times each for PuCR-ITS2 and Gra_probe_GU598051 primer-probe sets on each plate. The reaction analysis mode was set to FAM fluorophore, the setting was baseline subtracted curved fit, and the cycle threshold $\left(\mathrm{C}_{\mathrm{T}}\right)$ was set to automatically calculate single threshold. The cycling conditions were initial denaturation of $95^{\circ} \mathrm{C}$ for $120 \mathrm{~s}$, followed by 40 cycles of $95^{\circ} \mathrm{C}$ for $10 \mathrm{~s}$, then $55^{\circ} \mathrm{C}$ for $30 \mathrm{~s}$.

Real-time PCR sensitivity and optimization for detection. The Bio-Rad CFX Software manager was used for all analyses and to determine the $\mathrm{C}_{\mathrm{T}}$ values (Livak et al. 1995). Standard curves of PuCR-ITS2 and Gra_probe_GU598051 probes were evaluated to determine assay sensitivity. Amplification efficiency levels of the primer-probe sets were tested on two pUC57 plasmid vectors carrying the $P$. coronata and $P$. graminis insert constructed by Beirn et al. (2011) and kindly provided by JoAnne Crouch at the United States Department of AgricultureAgricultural Research Service in Beltsville, MD. A 10-fold template dilution series from $6.3 \times 10^{-2}$ to $6.3 \times 10^{-6} \mathrm{ng}$ of pUC57 plasmid with the $P$. coronata sequence insert were assayed with PuCR-ITS2 to test primer-probe set sensitivity. Similarly, a 10-fold dilution from 6.54 to $6.54 \times 10^{-5} \mathrm{ng}$ of plasmid P. graminis sequence were assayed with Gra_probe_GU598051. To examine probe mismatch with the nontemplates, $0,0.25,0.5,0.75$, and $1 \mathrm{ng}$ of $P$. coronata- and $P$. graminis-carrying plasmids were mixed such that, when there was a decrease in concentration of plasmid with $P$. coronata, there was an increase in concentration of plasmid with $P$. graminis, and vice versa (Fig. 1C). The assay was carried out in two separate reactions for the two probes.

The positive controls of $P$. coronata and $P$. graminis were obtained based on teliospore morphology, and the negative controls were genomic DNA of grass, genomic DNA of grass + fungi other than $P$. coronata and $P$. graminis, and water controls. When screening unknown samples, positive identifications of $P$. coronata and $P$. graminis were made by comparing their detectable fluorescence levels and $\mathrm{C}_{\mathrm{T}}$ values to the cut-off values obtained for negative water controls and positive $P$. coronata or $P$. graminis controls explained above.

PCR amplification and sequencing. PCR amplification and sequencing of the ITS region were conducted on 59 sequences to confirm positive real-time PCR results, to identify Puccinia spp. other than $P$. coronata and $P$. graminis where neither probe gave a positive reaction, and to phylogenetically compare the ITS locus diversity in the Puccinia spp. Two primer pairs were designed from the GenBank accession numbers GU598056 and GU598051 that comprised the Puccinia-specific ITS regions (Beirn et al. 2011) (Table 1).

Sequence amplification was performed using KAPA 3G Plant PCR kit (KAPA Biosystem Inc.). Sample DNA ( $1 \mu \mathrm{l}$ of 0.1 to $1 \mathrm{ng} / \mu \mathrm{l})$ was added to $200 \mu \mathrm{l}$ of KAPA mastermix consisting of $0.2 \mu \mathrm{M}$ primers. Thermal cycling conditions were $94^{\circ} \mathrm{C}$ for $3 \mathrm{~min}$; followed by 35 cycles of $94^{\circ} \mathrm{C}$ for $30 \mathrm{~s}$, annealing at $55^{\circ} \mathrm{C}$ for $30 \mathrm{~s}$, and extension at $72^{\circ} \mathrm{C}$ for $45 \mathrm{~s}$; and a final extension for $10 \mathrm{~min}$ at $72^{\circ} \mathrm{C}$. The PCR amplicons were purified (Wizard SV Gel and PCR clean-up system; Promega Corp., Fitchburg, WI), and sequenced at the University of WisconsinMadison Biotechnology Center. Chromatograms of sequences were viewed on FinchTV program (http://jblseqdat.bioc.cam.ac.uk/gnmweb/ download/soft/FinchTV_1.4/doc/) to edit bases from either end and the resulting sequences without uncalled bases were queried in Basic Local Alignment Search Tool nucleotide (BLASTn). The sample sequences were labeled $P$. coronata, $P$. graminis, $P$. striiformis, or other species based on the most similar BLASTn results.

Phylogenetic analysis. A phylogenetic analysis was conducted on 44 of the 59 PCR-amplified sequences to provide additional insight into the genetic variation within the ITS region of each rust species. The 15 of the 59 sequences not used in the analysis were discarded due to poorquality DNA obtained during the extraction and amplification process. The sequences were submitted to GenBank (Supplementary Table S1) and contain the same sequence labels as those found in Figure 2. Sequences of five additional $P$. coronata GenBank accessions isolated from $\mathrm{KB}(n=2)$, TF $(n=2)$, and PR $(n=1)$ and an additional five $P$. graminis accessions (all from $\mathrm{KB}$ ) and one sequence of $P$. striiformis

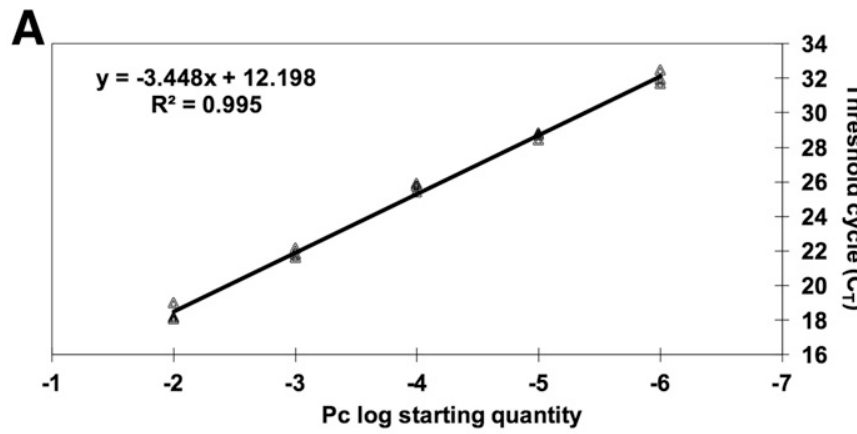

B
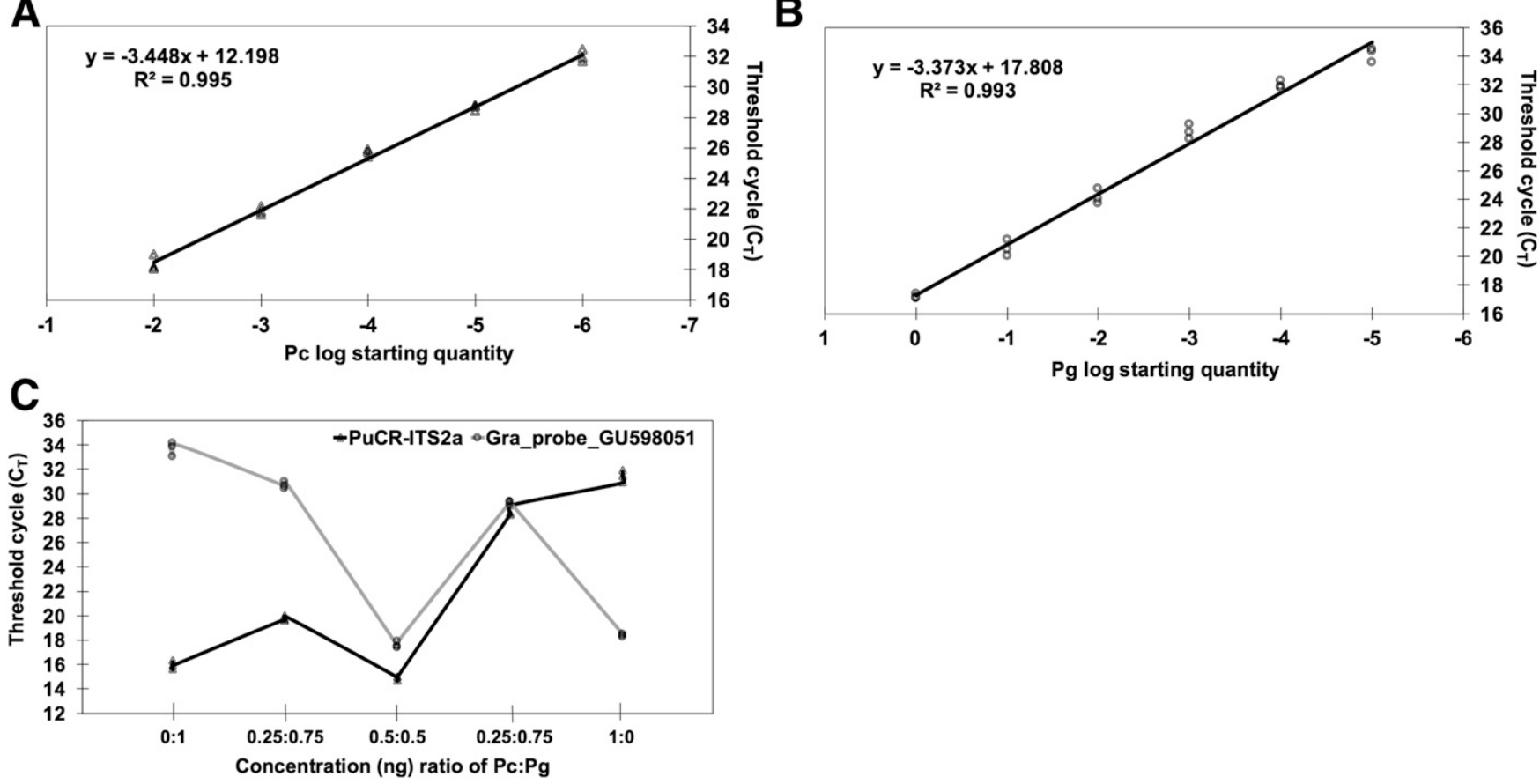

Fig. 1. A and B, Standard curves and C, probe mismatch for Puccinia coronata $(\mathrm{Pc})$ and $P$. graminis $(\mathrm{Pg})$ primer-probe efficiency. Each concentration point was replicated three times. A, $P$. coronata standard curve was created with log values of template plasmids from $6.3 \times 10^{-2} \mathrm{ng}$ starting concentration and diluted four 10 -fold dilutions to $6.3 \times 10^{-6} \mathrm{ng}$ to generate five points. B, $P$. graminis standard curve was created with log values of template plasmids from $6.54 \mathrm{ng}$ starting concentration and diluted five 10 -fold dilutions to $6.54 \times$ $10^{-5} \mathrm{ng}$ to generate six points. Coefficients of determination $\left(R^{2}\right)$ and slope are indicated in each of the two graphs. C, Probe mismatch with template plasmids containing $P$. coronata and $P$. graminis sequences. Concentrations in nanograms of both plasmids in ratio presented on the $\mathrm{c}$-axis. Probes are indicated in the plot. Threshold cycle $\left(\mathrm{C}_{\mathrm{T}}\right)$ values are indicated for the $y$-axis for the three assay plots. 
isolated from annual bluegrass (Роа аппиа) were added to the 44 sequences described above to support multiple alignment for phylogenetic analysis. Puccinia hordei (sequence KT982696 isolated from barley) was used as the outgroup to root the final tree. The labeled sequences were aligned in MEGA7 (Kumar et al. 2016) with ClustalW and saved in fasta file format. The phylogenetic relationships between the samples were estimated by loading the fasta files in a web-based platform (www. phylogeny.fr) with a one-click default option used by the web server that images use of maximum-likelihood phylogenetic analysis as implemented through PhyML. The option for curation by Gblocks was not employed because the sequences were already aligned by MEGA. Branch support was measured by the approximate likelihood ratio test

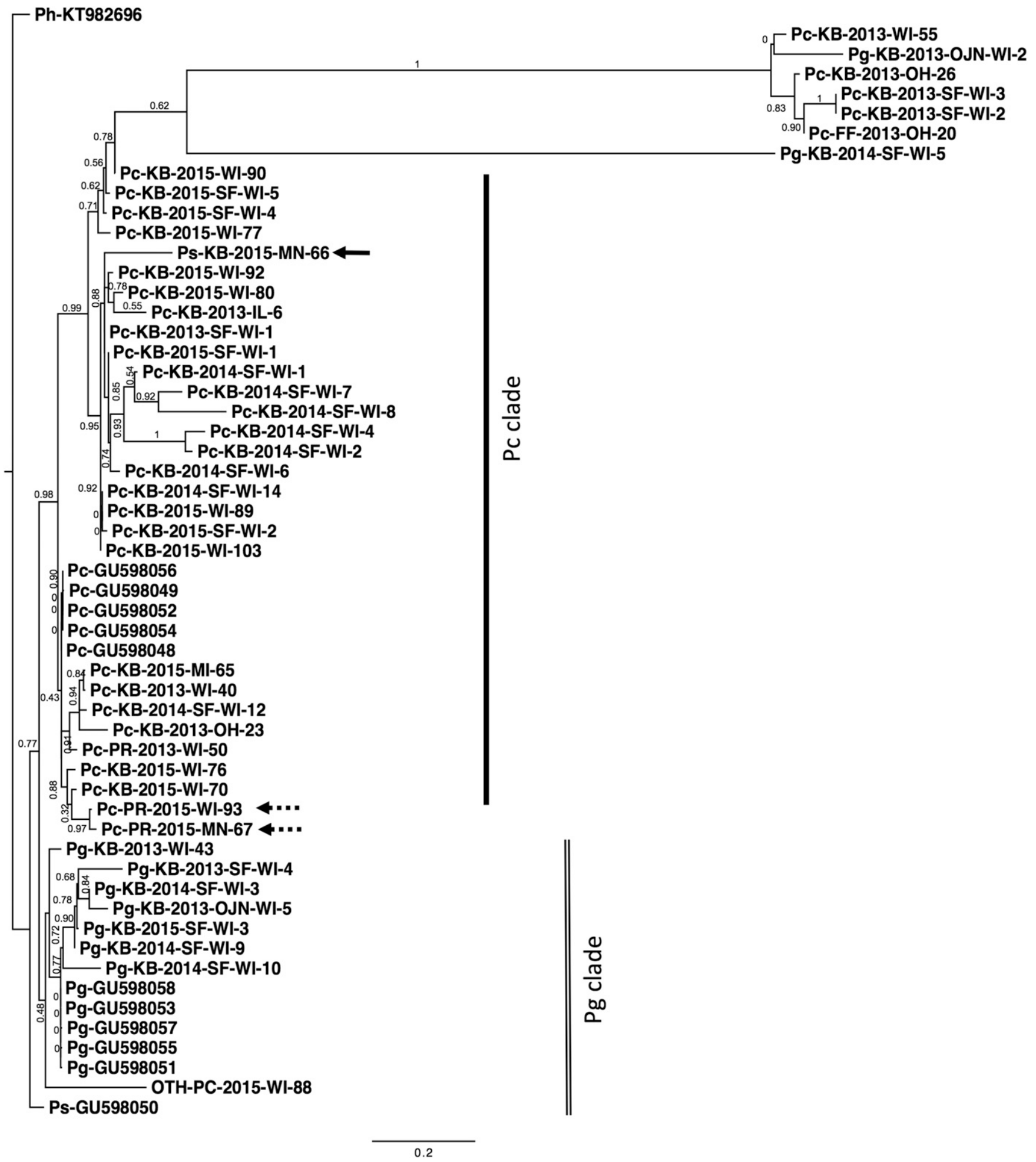

Fig. 2. Phylogenetic tree of 44 sequences with verified GenBank accessions of Puccinia coronata, $P$. graminis, $P$. striformis, and outgroup $P$. hordei. GenBank accession numbers are denoted. The sample name-labeling format is Puccinia sp.-grass species-year of sampling-samples from one time collection and repeat collections from two locations. The repeat collection locations are the $\mathrm{O}$. J. Noer Turfgrass Research and Education Facility (OJN) in Madison, WI, and a sod farm (SF) in southern Wisconsin. The Puccinia spp. included are $P$. coronata $(\mathrm{Pc}), P$. graminis $(\mathrm{Pg}), P$. striiformis $(\mathrm{Ps}), P$. hordei $(\mathrm{Ph})$, and other rust-causing fungi $(\mathrm{OTH})$. The grass species included are fine fescue (FF), Kentucky bluegrass (KB), prairie cordgrass (PC), and perennial ryegrass (PR). The horizontal solid arrow represents the $P$. striiformis sample on $P$. coronata clade and horizontal dotted arrows represent the two PR turfgrass samples with $P$. coronata. Number on the branches indicate the support values. The scale bar indicates the branch length, which is proportional to the number of base substitutions per site. 
(Guindon et al. 2010). The phylogenetic tree output was edited using Figtree, version 1.4.3 (http://tree.bio.ed.ac.uk/software/figtree/).

\section{Results}

Real-time PCR assay efficiency, sensitivity, and detection. The amplicon sizes for the real-time primers (Table 1) were $107 \mathrm{bp}$ for $P$. coronata and 124 bp for $P$. graminis. When $P$. coronata and $P$. graminis probe sequences were queried on the National Center for Biotechnology Information nr databases with BLASTn, the only matches found were for $P$. coronata and $P$. graminis. The coefficient of determination $\left(R^{2}\right)$ for the $P$. coronata standard curve was 0.995 and the amplification efficiency of PuCR-ITS2 was 95\% (Fig. 1A). The $R^{2}$ for the $P$. graminis standard curve was 0.993 and the amplification efficiency of Gra_probe_GU598051 was 98\% (Fig. 1B). The minimum DNA concentration point was at a $\mathrm{C}_{\mathrm{T}}$ value of 32 or less and the minimum DNA concentration required for valid $\mathrm{C}_{\mathrm{T}}$ was $6.31 \times 10^{-8} \mathrm{ng}$ for $P$. coronata and $6.54 \times 10^{-6} \mathrm{ng}$ for $P$. graminis.

Neither the P. coronata (PuCR-ITS2) nor the P. graminis (Gra_probe_ GU598051) probe matched with the opposite $P$. coronata or $P$. graminis plasmid template (Fig. 1C). The probes had higher $\mathrm{C}_{\mathrm{T}}$ values when their respective template concentration was lowered. Both probes had similar $\mathrm{C}_{\mathrm{T}}$ levels for their respective species template when the concentrations of the two plasmids were identical (Fig. 1C, third concentration point). Positive control samples for $P$. coronata or $P$. graminis consisted of one genomic DNA sample of each positively identified using teliospore morphology (mean $\mathrm{C}_{\mathrm{T}}$ for $P$. coronata or $P$. graminis $=20$ ). Noninfected grass genomic DNA, water controls, and DNA of grass + fungi other than $P$. coronata and $P$. graminis gave negative reactions for nonspecific amplifications $\left(\mathrm{C}_{\mathrm{T}}=32\right.$ or higher).

Real-time PCR identification. Of the 413 samples collected over the 3-year study, 20\% $(n=82)$ contained $P$. coronata, $67 \%(n=276)$ contained $P$. graminis, and $12 \%(n=51)$ contained both $P$. coronata and $P$. graminis (Table 2 ). The four remaining samples gave negative real-time results for both $P$. coronata and $P$. graminis.

There were 106 one-time samples collected from Wisconsin, other Midwestern states, and a sample from North Carolina between 2013 and 2015. Of these samples, 56\% were identified using real-time PCR as $P$. coronata $(n=59), 34 \%$ were identified as $P$. graminis $(n=36), 7 \%$ were identified as both $P$. coronata and $P$. graminis $(n=7)$, and $3 \%$ gave no results $(n=4)$ (Table 3$)$. Of the 106 total samples collected, 89 were KB. Only $P$. coronata was detected in $48 \mathrm{~KB}$ samples while only $P$. graminis were detected in 32.(Table 3). In seven of the KB samples, both $P$. coronata and $P$. graminis were detected while the remaining two KB gave negative results using real-time PCR. Nine PR samples were collected and only $P$. coronata was detected in all of them. Four tall fescue samples were collected and two contained $P$. coronata and two contained $P$. graminis. Two fine fescue samples were collected and $P$. coronata was detected on both. Two nonturf samples were also collected (prairie cordgrass [Spartina pectinata] and quackgrass [Agropyron repens]), and neither $P$. coronata nor $P$. graminis was detected in either using real-time PCR (Table 3).

There were 307 samples collected from the multiyear sites at OJN and SF from 2013 through 2015 and all were KB. Over all 3 years, $8 \%$ of the KB rust samples contained $P$. coronata $(n=24), 78 \%$ contained $P$. graminis $(n=239)$, and $14 \%$ contained both $P$. coronata and $P$. graminis $(n=44)$ (Table 4). In 2013, there were 135 samples collected from both sites and 101 of them were from the OJN. Of these 101 samples, $P$. graminis was detected on 98 samples while $P$. coronata was only detected in one sample and two other samples contained both $P$. graminis and $P$. coronata. The $34 \mathrm{SF}$ samples collected in 2013 contained 18 with $P$. graminis, 10 with $P$. coronata, and 6 with both $P$. graminis and $P$. coronata. There were 140 samples collected from OJN and SF in 2014 (Table 4). All 21 samples from the OJN contained $P$. graminis whereas 98 of 119 SF samples contained $P$. graminis, 2 contained $P$. coronata, and the remaining 19 contained both $P$. graminis and $P$. coronata. No rust was observed at the OJN in 2015 but $32 \mathrm{~KB}$ samples were collected from SF and they contained $11 P$. coronata, $4 P$. graminis, and 17 with both $P$. coronata and $P$. graminis (Table 4 ). The 2013 SF samples were approximately 40 times more likely than the OJN samples to have $P$. coronata on KB instead of $P$. graminis $(P<0.001)$ (Table 5). The KB samples from SF in 2015 were approximately six times more likely to contain $P$. coronata compared with $P$. graminis relative to the previous 2 years combined $(P<0.001)$ (Table 5). Rust severity was not assessed at either sampling site but, in general, it was observed that the most widespread rust occurred at both sites in 2013 and then decreased throughout 2014 and 2015.

PCR amplification and sequencing results. In total, 59 sequences from the 3-year study were selected for direct PCR amplicon sequencing. Of the 59 sequences, 44 gave chromatogram sequences of sufficient quality to give coverage during BLASTn searches. The remaining 15 sequences had low-quality chromatogram reads and were discarded from final analysis.

There were 2 sequences of the 44 with negative real-time results and where PCR amplicon sequencing gave rust fungi other than $P$. coronata and $P$. graminis. In the BLASTn search, one was a $P$. striiformis on a KB sample from a Minnesota arboretum (Table 3, sample 66). The other was a sample of rust on prairie cordgrass (S. pectinata) (Table 3, sample 88) that gave similarity to other Puccinia spp. These two sample sequences were added to the 42 sequences of $P$. coronata $(n=33)$ and $P$. graminis $(n=9)$ for phylogenetic analysis.

Phylogenetic analysis. The phylogenetic tree produced using the 44 PCR-amplified sequences (GenBank accessions MF772823 to MF772866) had two main clades, one clade of $P$. coronata samples and the other of $P$. graminis (Fig. 2). Interestingly, the two PR samples from Minnesota and Wisconsin in 2015 (Table 3, samples 67 and 93) formed a sister group on $P$. coronata (Fig. 2, horizontal

Table 2. Primers and probes for real-time polymerase chain reaction (PCR) and PCR amplification and sequencing used in this study

\begin{tabular}{|c|c|c|c|}
\hline Primer, probe, name & Sequence & Location & Primer designer \\
\hline \multicolumn{4}{|l|}{ Real-time PCR } \\
\hline \multicolumn{4}{|l|}{ Puccinia coronata } \\
\hline Cor_For_GU598056 & ATCATCACATCAAGGAAAGTAG & $552-584^{\mathrm{a}}$ & Current study \\
\hline Cor_Rev_GU598056 & GGTAGTCCCACCTGATTT & $651-699^{a}$ & Current study \\
\hline PuCR-ITS2 $2^{b}$ & FAM-TACTTGCCA/ZEN/TCTTTTGAAAGGAGGGA/31ABkFQ & $587-613^{\mathrm{a}}$ & Beirn et al. 2011 \\
\hline \multicolumn{4}{|c|}{ (1) } \\
\hline Gra_For_GU598051 & TAGGTGAACCTGCGGAA & $29-46^{\mathrm{c}}$ & Current study \\
\hline Gra_For_GU598051 & AATGATCTTTGACAGTCATGC & $64-96^{c}$ & Current study \\
\hline Gra_probe_GU598051 ${ }^{\mathrm{b}}$ & FAM-TTAGAGTGC/ZEN/ACTTTATTGTGGCTCAACTCTCT/31ABkFQ & $132-153^{\mathrm{c}}$ & Current study \\
\hline \multicolumn{4}{|c|}{ ( } \\
\hline GU598056_Coron_Seq FWD & TGGATCTCTAGGCTCTCACATC & $286-308^{a}$ & Current study \\
\hline GU598056_Coron_Seq REV & GCTTAAGTTCAGCGGGTAGTC & $662-683^{a}$ & Current study \\
\hline GU598051_Gra_Seq FWD & AACCTGCGGAAGGATCATTATTA & $35-58^{c}$ & Current study \\
\hline GU598051_Gra_Seq REV & GCAACACTCAACATCCACTAAAC & $460-483^{c}$ & Current study \\
\hline
\end{tabular}

${ }^{\mathrm{a}}$ Location based on GenBank accession number GU598056 P. coronata accession.

${ }^{\mathrm{b}} P$. coronata and $P$. graminis probes having 6-carboxy-flourescein (6-FAM) fluorescent reporter dye at $5^{\prime}$, internal quencher (ZEN) to enhance specificity, and Iowa Black Fluorescent quencher (31ABkFQ) at 3'.

${ }^{\mathrm{c}}$ Location based on GenBank Accession number GU598051 P. graminis accession. 
dotted arrows) with the 2013 groups (Table 3, sample 50) in the neighboring clade. The $P$. striiformis sample from KB from Minnesota (Table 3, sample 66) did not group with the verified $P$. striiformis accession GU598050 but instead grouped with the $P$. coronata clade (Fig. 2, horizontal arrow).

There were seven sequences of $P$. coronata $(n=5)$ and $P$. graminis $(n=2)$ that formed a separate clade from the two main $P$. coronata and $P$. graminis clades. Two of these were diagnosed as $P$. coronata from Ohio (one on fine fescue $[F$. rubra $]$ and the other on KB), and the remaining were from $\mathrm{OJN}(n=1), \mathrm{SF}(n=3)$, and a $\mathrm{KB}$ sample from a Wisconsin lawn. The $P$. striiformis GenBank accessions and the other Puccinia spp. (Table 3, sample 88) grouped with the outgroup ( $P$. hordei) but their relative positions were uncertain (low support values) and were unresolved.

\section{Discussion}

The results presented here found that $17 \%$ of $396 \mathrm{~KB}$ rust samples contained $P$. coronata, confirming earlier research from Beirn et al.

Table 3. Real-time polymerase chain reaction (PCR) rust identification, grass species, year, state, city, and industry segment for turfgrass rust samples collected and received from cooperators around the Midwestern United States between 2013 and 2015

\begin{tabular}{|c|c|c|c|c|c|c|}
\hline Sample & Pathogen ID $^{\mathbf{a}}$ & Grass species $^{\mathbf{b}}$ & Year & State & City & Industry segment \\
\hline 1 & Puccinia coronata & KB & 2013 & IL & Elgin & Lawn \\
\hline 2 & P. coronata & $\mathrm{KB}$ & 2013 & $\mathrm{IL}$ & Elgin & Lawn \\
\hline 3 & P. graminis & KB & 2013 & $\mathrm{IL}$ & Elgin & Lawn \\
\hline 4 & Both & KB & 2013 & $\mathrm{IL}$ & Gilberts & Lawn \\
\hline 5 & P. graminis & KB & 2013 & $\mathrm{IL}$ & Hampshire & Lawn \\
\hline 6 & P. coronata & KB & 2013 & $\mathrm{IL}$ & Manteno & Sod \\
\hline 7 & P. coronata & $\mathrm{KB}$ & 2013 & $\mathrm{IL}$ & Manteno & Sod \\
\hline 8 & P. graminis & $\mathrm{KB}$ & 2013 & $\mathrm{MN}$ & Lakeville & Lawn \\
\hline 9 & P. coronata & PR & 2013 & MN & Lakeville & Lawn \\
\hline 10 & P. coronata & KB & 2013 & MN & Mankato & Lawn \\
\hline 11 & P. coronata & $\mathrm{KB}$ & 2013 & MN & St. Paul & Lawn \\
\hline 12 & P. graminis & $\mathrm{KB}$ & 2013 & MN & Savage & Lawn \\
\hline 13 & P. graminis & $\mathrm{TF}$ & 2013 & $\mathrm{NC}$ & Durham & Pasture \\
\hline 14 & P. graminis & $\mathrm{PC}$ & 2013 & $\mathrm{OH}$ & Columbus & Roadside \\
\hline 15 & P. coronata & KB & 2013 & $\mathrm{OH}$ & Columbus & Lawn \\
\hline 16 & P. graminis & $\mathrm{KB}$ & 2013 & $\mathrm{OH}$ & Columbus & Lawn \\
\hline 17 & P. graminis & KB & 2013 & $\mathrm{OH}$ & Columbus & Lawn \\
\hline 18 & P. graminis & KB & 2013 & $\mathrm{OH}$ & Columbus & Lawn \\
\hline 19 & P. graminis & $\mathrm{KB}$ & 2013 & $\mathrm{OH}$ & Columbus & Lawn \\
\hline 20 & P. coronata & $\mathrm{FF}$ & 2013 & $\mathrm{OH}$ & Columbus & Roadside \\
\hline 21 & P. coronata & $\mathrm{KB}$ & 2013 & $\mathrm{OH}$ & Galena & Lawn \\
\hline 22 & Other & $\mathrm{KB}$ & 2013 & $\mathrm{OH}$ & Galena & Lawn \\
\hline 23 & P. coronata & $\mathrm{KB}$ & 2013 & $\mathrm{OH}$ & Lewis Center & Sod \\
\hline 24 & P. coronata & $\mathrm{KB}$ & 2013 & $\mathrm{OH}$ & Lewis Center & Sod \\
\hline 25 & P. coronata & $\mathrm{KB}$ & 2013 & $\mathrm{OH}$ & Lewis Center & Sod \\
\hline 26 & P. coronata & $\mathrm{KB}$ & 2013 & $\mathrm{OH}$ & London & Lawn \\
\hline 27 & P. coronata & $\mathrm{KB}$ & 2013 & WI & Brodhead & Lawn \\
\hline 28 & P. graminis & $\mathrm{KB}$ & 2013 & WI & Coloma & Sod \\
\hline 29 & P. coronata & $\mathrm{KB}$ & 2013 & WI & Cross Plains & Lawn \\
\hline 30 & P. coronata & $\mathrm{KB}$ & 2013 & WI & Cross Plains & Lawn \\
\hline 31 & P. graminis & $\mathrm{KB}$ & 2013 & WI & Franksville & Sod \\
\hline 32 & P. graminis & $\mathrm{KB}$ & 2013 & WI & Franksville & Sod \\
\hline 33 & P. graminis & $\mathrm{KB}$ & 2013 & WI & Franksville & Sod \\
\hline 34 & P. graminis & $\mathrm{KB}$ & 2013 & WI & Franksville & Sod \\
\hline 35 & P. coronata & $\mathrm{KB}$ & 2013 & WI & Jefferson & School \\
\hline 36 & P. graminis & $\mathrm{KB}$ & 2013 & WI & Lancaster & Sports field \\
\hline 37 & P. coronata & $\mathrm{FF}$ & 2013 & WI & McFarland & Lawn \\
\hline 38 & P. coronata & $\mathrm{KB}$ & 2013 & WI & Neenah & Lawn \\
\hline 39 & P. graminis & $\mathrm{KB}$ & 2013 & WI & Oregon & Lawn \\
\hline 40 & P. coronata & $\mathrm{KB}$ & 2013 & WI & Oregon & School \\
\hline 41 & P. coronata & $\mathrm{KB}$ & 2013 & WI & Sun Prairie & Lawn \\
\hline 42 & P. graminis & $\mathrm{KB}$ & 2013 & WI & Union Grove & Sod \\
\hline 43 & P. graminis & $\mathrm{KB}$ & 2013 & WI & Verona & Lawn \\
\hline 44 & P. graminis & $\mathrm{KB}$ & 2013 & WI & Verona & Lawn \\
\hline 45 & P. graminis & $\mathrm{KB}$ & 2013 & WI & Verona & Lawn \\
\hline 46 & P. graminis & $\mathrm{KB}$ & 2013 & WI & Verona & Lawn \\
\hline 47 & P. graminis & $\mathrm{KB}$ & 2013 & WI & Verona & Lawn \\
\hline 48 & P. graminis & $\mathrm{KB}$ & 2013 & WI & Verona & Lawn \\
\hline 49 & Both & $\mathrm{KB}$ & 2013 & WI & Verona & Lawn \\
\hline 50 & P. coronata & PR & 2013 & WI & Verona & Lawn \\
\hline
\end{tabular}

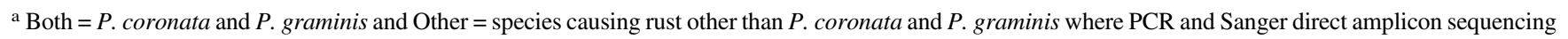
were conducted.

${ }^{\mathrm{b}}$ Grass species: $\mathrm{FF}=$ fine fescue $($ Festuca rubra), $\mathrm{KB}=$ Kentucky bluegrass $($ Poa pratensis $), \mathrm{PC}=$ prairie cordgrass $($ Spartina pectinata $), \mathrm{PR}=$ perennial rye (Lolium perenne $\mathrm{L}$.), $\mathrm{Q}=$ quackgrass (Agropyron repens), $\mathrm{TF}=$ tall fescue (Festuca arundinacea), and $\mathrm{KB} / \mathrm{TF}=\mathrm{Kentucky}$ bluegrass and tall fescue mix.

${ }^{c}$ States are denoted with two-letter codes: $\mathrm{IL}=$ Illinois, $\mathrm{IN}=$ Indiana, $\mathrm{MI}=$ Michigan, $\mathrm{MN}=$ Minnesota, $\mathrm{MO}=\mathrm{Missouri}, \mathrm{NC}=\mathrm{North} \mathrm{Carolina}, \mathrm{OH}=\mathrm{Ohio}$, and $\mathrm{WI}=\mathrm{Wisconsin}$. 
(2011) that indicated that $\mathrm{KB}$ is a relatively common host of $P$. coronata. Host specificity has been a key identifying characteristic of turfgrass rusts on $\mathrm{KB}$ and PR for decades, and it has also been used for identifying Puccinia spp. in other grass hosts, including bentgrass (Agrostis spp.), brome grass (Bromus spp.) (Liu and Hambleton 2013), and barley (Jafary et al. 2008). This lack of host specificity will likely play an important role in future turfgrass breeding and rust management strategies. For example, the ability of $P$. coronata to sexually reproduce using common buckthorn will lead to more rapid evolution of races that can evade $\mathrm{KB}$ host defenses and cause symptoms on a broadening array of turfgrass species. Beirn et al. (2011) discussed how new races of $P$. coronata in cereal pathosystems evolve by sexual recombination and random mutations that increased pathogen virulence and eventually allowed the pathogen to infect other grass hosts. Rust research in oat can be used to predict evolutionary responses in turfgrass because clusters of resistant genes have been found conserved in genetically equivalent regions of oat (Avena sativa) and PR to their two forma speciales of $P$. coronata (Dumsday et al. 2003). To account for this increased adaptability, turfgrass breeders must either include more durable forms of host

Table 3. (Continued from previous page)

\begin{tabular}{|c|c|c|c|c|c|c|}
\hline Sample & Pathogen ID & Grass species $^{b}$ & Year & State $^{c}$ & City & Industry segment \\
\hline 51 & P. coronata & PR & 2013 & WI & Verona & Lawn \\
\hline 52 & P. coronata & PR & 2013 & WI & Verona & Lawn \\
\hline 53 & P. coronata & $\mathrm{TF}$ & 2013 & WI & Verona & Lawn \\
\hline 54 & Other & $\mathrm{Q}$ & 2013 & WI & Verona & Prairie \\
\hline 55 & P. coronata & $\mathrm{KB}$ & 2013 & WI & Waukesha & Lawn \\
\hline 56 & Both & KB & 2013 & WI & Whitewater & Sod \\
\hline 57 & P. coronata & $\mathrm{KB}$ & 2014 & IL & Lemont & Golf Course \\
\hline 58 & P. graminis & $\mathrm{KB} / \mathrm{TF}$ & 2014 & MO & Columbia & Lawn \\
\hline 59 & P. coronata & $\mathrm{PR}$ & 2014 & MO & Columbia & Lawn \\
\hline 60 & P. coronata & PR & 2014 & MO & Columbia & Lawn \\
\hline 61 & P. coronata & KB & 2014 & WI & Middleton & Field \\
\hline 62 & P. coronata & KB & 2014 & WI & Verona & Lawn \\
\hline 63 & P. coronata & KB & 2015 & IN & Purdue Turf & Lawn \\
\hline 64 & P. graminis & $\mathrm{KB}$ & 2015 & IN & Purdue Turf & Lawn \\
\hline 65 & P. coronata & KB & 2015 & MI & Grand Rapids & Lawn \\
\hline 66 & Other & KB & 2015 & $\mathrm{MN}$ & Chaska & Arboretum \\
\hline 67 & P. coronata & PR & 2015 & MN & Chaska & Arboretum \\
\hline 68 & P. coronata & $\mathrm{KB}$ & 2015 & $\mathrm{MN}$ & Fergus Falls & Lawn \\
\hline 69 & P. graminis & KB & 2015 & WI & Ashland & Lawn \\
\hline 70 & Both & KB & 2015 & WI & Bristol & Lawn \\
\hline 71 & P. graminis & $\mathrm{KB}$ & 2015 & WI & Brodhead & Homeowner \\
\hline 72 & P. coronata & KB & 2015 & WI & Cobb & Sports field \\
\hline 73 & P. coronata & $\mathrm{KB}$ & 2015 & WI & Cross Plains & Homeowner \\
\hline 74 & P. coronata & $\mathrm{TF}$ & 2015 & WI & Cross Plains & Homeowner \\
\hline 75 & P. graminis & $\mathrm{KB}$ & 2015 & WI & Delevan & Sod \\
\hline 76 & Both & $\mathrm{KB}$ & 2015 & WI & Dodgeville & Lawn \\
\hline 77 & P. coronata & $\mathrm{KB}$ & 2015 & WI & Eagle & Homeowner \\
\hline 78 & Both & KB & 2015 & WI & Green Bay & Homeowner \\
\hline 79 & P. coronata & KB & 2015 & WI & Jefferson & Homeowner \\
\hline 80 & P. coronata & $\mathrm{KB}$ & 2015 & WI & Kansasville & Sod \\
\hline 81 & P. graminis & KB & 2015 & WI & Kaukauna & Lawn \\
\hline 82 & P. coronata & $\mathrm{KB}$ & 2015 & WI & Lancaster & $\mathrm{AF}$ \\
\hline 83 & P. coronata & $\mathrm{KB}$ & 2015 & WI & Madison & Homeowner \\
\hline 84 & P. coronata & KB & 2015 & WI & Madison & Homeowner \\
\hline 85 & P. coronata & $\mathrm{KB}$ & 2015 & WI & Madison & Homeowner \\
\hline 86 & P. coronata & $\mathrm{KB}$ & 2015 & WI & Madison & Homeowner \\
\hline 87 & P. coronata & $\mathrm{KB}$ & 2015 & WI & Madison & Homeowner \\
\hline 88 & Other & $\mathrm{PC}$ & 2015 & WI & Madison & Homeowner \\
\hline 89 & P. coronata & $\mathrm{KB}$ & 2015 & WI & Madison & Lawn \\
\hline 90 & P. coronata & KB & 2015 & WI & Manitowoc & Lawn \\
\hline 91 & P. coronata & $\mathrm{KB}$ & 2015 & WI & McFarland & School \\
\hline 92 & Both & $\mathrm{KB}$ & 2015 & WI & Middleton & Lawn \\
\hline 93 & P. coronata & PR & 2015 & WI & Middleton & Lawn \\
\hline 94 & P. coronata & $\mathrm{KB}$ & 2015 & WI & Milwaukee & Lawn \\
\hline 95 & P. coronata & $\mathrm{KB}$ & 2015 & WI & Oregon & Sports field \\
\hline 96 & P. graminis & $\mathrm{KB}$ & 2015 & WI & Whitewater & Sod \\
\hline 97 & P. graminis & $\mathrm{KB}$ & 2015 & WI & Whitewater & Sod \\
\hline 98 & P. coronata & $\mathrm{KB}$ & 2015 & WI & Watertown & Lawn \\
\hline 99 & P. coronata & $\mathrm{KB}$ & 2015 & WI & Sparta & Lawn \\
\hline 100 & P. graminis & $\mathrm{KB}$ & 2015 & WI & Sullivan & Sod \\
\hline 101 & P. graminis & $\mathrm{KB}$ & 2015 & WI & Sullivan & Sod \\
\hline 102 & P. graminis & KB & 2015 & WI & Sullivan & Sod \\
\hline 103 & P. coronata & $\mathrm{KB}$ & 2015 & WI & Verona & Lawn \\
\hline 104 & P. coronata & KB & 2015 & WI & Verona & Lawn \\
\hline 105 & P. coronata & $\mathrm{KB}$ & 2015 & WI & Verona & Sports field \\
\hline 106 & P. graminis & $\mathrm{KB}$ & 2015 & WI & Wauwatosa & Lawn \\
\hline
\end{tabular}


resistance into future $\mathrm{KB}$ breeding lines or develop resistant $\mathrm{KB}$ cultivars at a faster rate to account for more rapid pathogen evolution (Bonos et al. 2006; Pfender 2009).

Rapid development of rust-resistant $\mathrm{KB}$ cultivars might not be practical for the consumer. Turfgrass lawns and athletic fields are generally maintained for many years, and if Puccinia spp. evolve rapidly to infect resistant KB cultivars then the consumer may be completely reliant on cultural and chemical management strategies for suppressing rust development shortly after planting (Bozdogan 2014; Smiley 1981). In Wisconsin, however, sod producers have observed that recent rust outbreaks were most severe in the first 1 to 2 years after seeding and decreased in severity in subsequent years (Tom Halter, personal communication). This study also observed that same phenomenon, because general rust severity appeared to decrease over time at both the OJN and SF despite the environment generally appearing to be conducive for rust development in all 3 years. If this were accurate on a larger scale, breeding efforts would be instrumental in providing host resistance for the first couple of years until environmental, physiological, or cultural conditions can be effective at mitigating rust outbreaks as the plant matures.

Differences in the distribution of $P$. coronata and $P$. graminis on KB were observed at the SF and OJN in 2013, which sit approximately $80 \mathrm{~km}$ away from each other. These differences may be related to the local environmental conditions at each site. The SF site sits on a ridge of relatively unfertile mineral soil, whereas the OJN is situated on more fertile silt loam soils near a drainage swale. Previous research observed that high-nitrogen soil amended by composed biosolids suppressed leaf rust (Puccinia spp.) for up to 9 weeks on PR (Loschinkohl and Boehm 2001); thus, it is possible that soil fertility affected the Puccinia spp. distribution between the sites. Differences in $P$. coronata and $P$. graminis distribution were also observed depending on the year when OJN and SF were sampled, which may indicate that different weather conditions can favor

Table 4. Puccinia spp. identification using real-time polymerase chain reaction on Kentucky bluegrass at two locations in southern Wisconsin between 2013 and 2015

\begin{tabular}{llccc}
\hline Year & Location $^{\mathbf{a}}$ & Puccinia coronata & P. graminis & Both $^{\mathbf{b}}$ \\
\hline 2013 & SF & 10 & 18 & 6 \\
& OJN & 1 & 98 & 2 \\
2014 & OJN & 0 & 21 & 0 \\
& SF & 2 & 98 & 19 \\
2015 & SF & 11 & 4 & 17 \\
\hline
\end{tabular}

${ }^{\mathrm{a}} \mathrm{SF}=$ sod farm in Southern Wisconsin and OJN $=$ O. J. Noer Turfgrass

Research and Education Facility, Madison, WI.

${ }^{\mathrm{b}}$ Both $=P$. coronata and $P$. graminis. one Puccinia sp. over another. Weather data for Madison, WI during June, July, August, and September from 2013 through 2015 showed only minor differences in temperature and relative humidity among years. However, 2013 and 2014 both had higher rain totals compared with 2015 (49.7, 50.5, and $46.2 \mathrm{~cm}$, respectively) and, in particular, rainfall was very heavy in June and then tapered off in August and September in both 2013 and 2014. Whether rainfall or other environmental factors play a role in rust occurrence remains unclear but would be a key area for additional research in order to implement site-specific rust control strategies.

PCR amplification and phylogenetic analysis of a subset of samples resulted in $P$. coronata and $P$. graminis clades that grouped separately for the ITS locus. No major differences within species level in either the $P$. coronata or $P$. graminis sequences were observed. The $P$. coronata sequences from PR from both Wisconsin $(n=2)$ and Minnesota $(n=1)$ grouped within the 27 P. coronata sequences on KB. Similarly, the SF and OJN samples also formed sister clades and were relatively similar to each other. A clade having seven sequences was generated on a longer branch because they did not align with the rest of the sequences of the main tree. Previous work by Liu et al. (2015) demonstrated that subspecies groups within $P$. graminis and $P$. striiformis can be obtained using a greater taxonomic circumscription with additional gene loci other than ITS, including $\beta$-tubulin, cytochrome c oxidase subunit 1, and RNA polymerase II second largest subunit. Such larger-scale resolution is required to decipher whether subspecies levels of $P$. coronata and $P$. graminis exist within the population reported in this study.

Multiple Puccinia spp. were detected on the same plant in 51 of the 413 samples in this study. The presence of both $P$. coronata and $P$. graminis on the same turfgrass plant has been observed previously (Integrated Pest Management 1987), though what impacts might arise when multiple rust species infect simultaneously remains unclear. There have been reports of interactions of multiple pathogens on single plant hosts with impacts on disease severity (Lamichhane and Venturi 2015). For example, the synergistic interactions between Potato virus $X$ and Potato virus $Y$ led to increased systemic infection in tobacco (Nicotiana benthamiana) and changes were observed in oxidative stress and transcription at the cellular level (García-Marcos et al. 2009). Another synergism was reported by Kaur et al. (2011) in mustard (Brassica juncea), where Albugo candida causing white rust appeared earlier and was more severe when a downy mildew-resistant mustard variety was preinoculated with the downy mildew pathogen (Hyaloperonospora parasitica). On the other hand, antagonistic effects have also been observed in pathogenic interactions such as different clonal strains of Pseudomonas syringae being reduced in populations with mixed inoculation over individual inoculation on kiwifruit bacterial canker (Bartoli et al. 2015). The two pathogens Mycosphaerella

Table 5. Fisher's exact test to determine the odds of different Puccinia spp. distributions on Kentucky bluegrass samples from a sod farm in southern Wisconsin (SF) compared with the O. J. Noer Turfgrass Research Facility in Madison, WI (OJN) in 2013 and also within the sod farm from 2013 to 2015

\begin{tabular}{|c|c|c|c|c|c|c|c|}
\hline \multirow[b]{2}{*}{ Comparison $^{\mathrm{a}}$} & \multicolumn{2}{|c|}{ Location } & \multicolumn{2}{|c|}{ Year } & \multicolumn{3}{|c|}{ Fisher's exact test } \\
\hline & SF & OJN & 2015 & 2013-14 & Odds ratio & $95 \% \mathrm{CI}^{\mathrm{b}}$ & $P$ value \\
\hline \multicolumn{8}{|l|}{ SF vs. OJN in 2013} \\
\hline P. coronata & 10 & 1 & $\ldots$ & $\ldots$ & 40.250 & $5.293-1,806.367$ & $<0.001$ \\
\hline No $P$. coronata & 24 & 100 & $\ldots$ & $\ldots$ & $\ldots$ & $\ldots$ & \\
\hline P. graminis & 18 & 98 & $\ldots$ & $\ldots$ & 0.036 & $0.006-0.142$ & 0.04 \\
\hline No $P$. graminis & 16 & 3 & $\ldots$ & $\ldots$ & $\ldots$ & $\ldots$ & $\ldots$ \\
\hline Both & 6 & 2 & $\ldots$ & $\ldots$ & 10.377 & $1.734-110.580$ & 0.003 \\
\hline No Both & 28 & 99 & $\ldots$ & $\ldots$ & $\ldots$ & $\ldots$ & $\ldots$ \\
\hline \multicolumn{8}{|c|}{2015 vs. $2013-14$ in SF } \\
\hline P. coronata & $\ldots$ & $\ldots$ & 11 & 12 & 6.066 & $2.133-17.300$ & $<0.001$ \\
\hline No $P$. coronata & $\ldots$ & $\ldots$ & 21 & 141 & $\ldots$ & $\ldots$ & $\ldots$ \\
\hline P. graminis & $\ldots$ & $\ldots$ & 4 & 116 & 0.046 & $0.011-0.145$ & $<0.001$ \\
\hline No $P$. graminis & $\ldots$ & $\ldots$ & 28 & 37 & $\ldots$ & $\ldots$ & $\ldots$ \\
\hline Both & $\ldots$ & $\ldots$ & 17 & 25 & 5.729 & $2.357-14.183$ & $<0.001$ \\
\hline No Both & $\ldots$ & $\ldots$ & 15 & 128 & $\ldots$ & $\ldots$ & $\ldots$ \\
\hline
\end{tabular}

a Both $=$ P. coronata and $P$. graminis.

${ }^{\mathrm{b}} \mathrm{CI}=$ confidence interval. 
pinodes and Phoma medicaginis var. pinodella are part of the Ascochyta blight complex on field pea (Pisum sativum) and exhibited antagonism where the single inoculation of the former resulted in higher pycnidia and lesions than when inoculated together with latter (Le May et al. 2009) The coinfection of turfgrass plants with multiple rust species appears to be somewhat common and the synergistic or antagonistic effects that Puccinia coronata and P. graminis have on each other while present on turfgrass leaf tissue warrant further examination.

Though both real-time PCR and traditional PCR amplification and sequencing were used in this study to identify rust species, PCR amplification and sequencing is not a consistently effective method for rust identification moving forward due to the low amounts of fungal DNA available from Puccinia urediniospores embedded in turfgrass leaves. Real-time PCR is the preferred method due to its ability to detect DNA at low concentrations, and its specificity for $P$. coronata and $P$. graminis reduces the risk of false positives or negatives and potential contamination from airborne spores. Previous studies have either directly harvested urediniospores (Beirn et al. 2011) or used a very large quantity (Barnes and Szabo 2007) but both can be time consuming and impractical in many situations. However, PCR amplification and sequencing did enable us to confirm real-time PCR identification, verify any negative real-time detection, and identify multiple Puccinia spp. infections in the same plant. Additional studies using real-time probes designed for other Puccinia spp. will broaden the understanding the spread of Puccinia spp. other than $P$. coronata or $P$. graminis in Midwestern states.

Rust fungi are important pathogens of turfgrass that are highly dynamic and constantly evolving. Recent work on rusts in other pathosystems has improved our understanding of rust ecology and epidemiology, most notably related to $P$. coronata marker populations (Muylle et al. 2005), disease-predictive modeling for stem rust (Pfender et al. 2015), and improved breeding for rust-resistant cultivars (Sim et al. 2007). Additional work that can further aid rust management in turf and other grass crops includes the impact of simultaneous infection by multiple rust pathogens on disease severity, geographic and temporal impacts on Puccinia spp. distribution, and further development of molecular diagnostic tools to aid in the tracking of rust pathogens at the species and subspecies level. The results presented here and the research that follows will eventually aid turfgrass breeders and turfgrass managers in developing rust management that are more effective, efficient, durable, and sustainable.

\section{Acknowledgments}

We thank J. A. Crouch for providing positive control plasmids for $P$. coronata and P. graminis; S. Bauer, J. Rimelspach, L. Miller, and C. Bigelow for submitting Puccinia-infected turfgrass samples from their respective states; A. Charkowski, D. Smith, and S. Thomas-Sharma for helpful discussions and critical reviews of the manuscript; and C. Ané and M. Kamenetsky for providing critical help with phylogenetic tree construction and statistical analysis, respectively.

\section{Literature Cited}

Barnes, C. W., and Szabo, L. J. 2007. Detection and identification of four common rust pathogens of cereals and grasses using real-time polymerase chain reaction. Phytopathology 97:717-727.

Bartoli, C., Lamichhane, J. R., Berge, O., Guilbaud, C., Varvaro, L., Balestra, G. M., Vinatzer, B. A., and Morris, C. E. 2015. A framework to gauge the epidemic potential of plant pathogens in environmental reservoirs: The example of kiwifruit canker. Mol. Plant Pathol. 16:137-149.

Beirn, L. A., Moy, M., Meyer, W. A., Clarke, B. B., and Crouch, J. A. 2011. Molecular analysis of turfgrass rusts reveals the widespread distribution of Puccinia coronata as a pathogen of Kentucky Bluegrass in the United States. Plant Dis. 95:1547-1557.

Bockus, W. W., Bowden, R. L., Hunger, R. M., Morrill, W. L., Murray, T. D., and Smiley, R. W. 2010. Compendium of Wheat Diseases and Pests, 3rd ed. American Phytopathological Society, St. Paul, MN.

Bonos, S. A., Clarke, B. B., and Meyer, W. A. 2006. Breeding for disease resistance in the major cool-season turfgrasses. Annu. Rev. Phytopathol. 44:213-234.

Bozdogan, A. M. 2014. Assessment of total risk on non-target organisms in fungicide application for agricultural sustainability. Sustainability 6:1046-1058.

Campbell, C. L., and Long, D. L. 2001. The campaign to eradicate the common barberry in the United States. Pages 16-50 in: Stem Rust of Wheat: From Ancient Enemy to Modern Foe. P. D. Peterson, ed. American Phytopathological Society, St. Paul, MN.

Dumsday, J. L., Smith, K. F., Forster, J. W., and Jones, E. S. 2003. SSR-based genetic linkage analysis of resistance to crown rust (Puccinia coronata f. sp. lolii) in perennial ryegrass (Lolium perenne). Plant Pathol. 52:628-637.
Elder, R. T., Loh, E. Y., and Davis, R. W. 1983. RNA from the yeast transposable element Ty1 has both ends in the direct repeats, a structure similar to retrovirus. Proc. Natl. Acad. Sci. USA 80:2432-2436.

Frey, K. J., Browing, J. A., and Simons, M. D. 1973. Management of host resistance genes to control diseases. J. Plant Dis. Prot. 80:160-180.

García-Marcos, A., Pacheco, R., Martiáñez, J., González-Jara, P., Díaz-Ruíz, J. R., and Tenllado, F. 2009. Transcriptional changes and oxidative stress associated with the synergistic interaction between Potato virus $X$ and Potato virus $Y$ and their relationship with symptom expression. Mol. Plant-Microbe Interact. 22:1431-1444.

Guindon, S., Dufayard, J.-F., Lefort, V., Anisimova, M., Hordijk, W., and Gascuel, O. 2010. New algorithms and methods to estimate maximum-likelihood phylogenies: Assessing the performance of PhyML 3.0. Syst. Biol. 59:307-321.

Harshberger, J. W. 1917. A Text-Book of Mycology and Plant Pathology. P. Blakiston's Son \& Co., Philadelphia.

Integrated Pest Management. 1987. Rusts of turfgrasses. Integrated Pest Management, University of Illinois, Urbana-Champaign. http://ipm.illinois. edu/diseases/series400/rpd412/

Jafary, H., Albertazzi, G., Marcel, T. C., and Niks, R. E. 2008. High diversity of genes for nonhost resistance of barley to heterologous rust fungi. Genetics $178: 2327-2339$

Kaur, P., Sivasithamparam, K., Li, H., and Barbetti, M. J. 2011. Pre-inoculation with Hyaloperonospora parasitica reduces incubation period and increases severity of disease caused by Albugo candida in a Brassica juncea variety resistant to downy mildew. J. Gen. Plant Pathol. 77:101-106.

Kolmer, J. A. 2005. Tracking wheat rust on a continental scale. Curr. Opin. Plant Biol. 8:441-449.

Kumar, S., Stecher, G., and Tamura, K. 2016. MEGA7: Molecular evolutionary genetics analysis version 7.0 for bigger datasets. Mol. Biol. Evol. 33:1870-1874

Lamichhane, J. R., and Venturi, V. 2015. Synergisms between microbial pathogens in plant disease complexes: A growing trend. Front. Plant Sci. 6:385

Le May, C., Potage, G., Andrivon, D., Tivoli, B., and Outreman, Y. 2009. Plant disease complex: Antagonism and synergism between pathogens of the Ascochyta blight complex on pea. J. Phytopathol. 157:715-721.

Leonard, K. J., and Szabo, L. J. 2005. Stem rust of small grains and grasses caused by Puccinia graminis. Mol. Plant Pathol. 6:99-111.

Liu, M., and Hambleton, S. 2013. Laying the foundation for a taxonomic review of Puccinia coronata s.1. in a phylogenetic context. Mycol. Prog. 12:63-89.

Liu, M., McCabe, E., Chapados, J. T., Carey, J., Wilson, S. K., Tropiano, R., Redhead, S. A., Lévesque, C. A., and Hambleton, S. 2015. Detection and identification of selected cereal rust pathogens by TaqMan real-time PCR. Can. J. Plant Pathol. 37:92-105.

Livak, J. L., Marmaro, J., and Todd, J. A. 1995. Towards fully automated genomewide polymorphism screening. Nat. Genet. 9:341-342.

Loschinkohl, C., and Boehm, M. J. 2001. Composted biosolids incorporation improves turfgrass establishment on disturbed urban soil and reduces leaf rust severity. HortScience 36:790-794.

Muylle, H., Baert, J., Van Bockstaele, E., Pertijs, J., and Roldán-Ruiz, I. 2005. Four QTLs determine crown rust (Puccinia coronata f. sp. lolii) resistance in a perennial ryegrass (Lolium perenne) population. Heredity 95:348-357.

Nagarajan, S., and Singh, D. V. 1990. Long-distance dispersion of rust pathogens. Annu. Rev. Phytopathol. 28:139-153.

Pfender, W. 2009. Demonstration of pathotype specificity in stem rust of perennial ryegrass. Phytopathology 99:1185-1189.

Pfender, W. F., Coop, L. B., Seguin, S. G., Mellbye, M. E., Gingrich, G. A., and Silberstein, T. B. 2015. Evaluation of the ryegrass stem rust model STEMRUST_G and its implementation as a decision aid. Phytopathology 105:35-44.

Potter, L. R. 1987. Effect of crown rust on regrowth, competitive ability and nutritional quality of perennial and Italian ryegrasses. Plant Pathol. 36:455-461.

R Core Team. 2015. R: A Language and Environment for Statistical Computing. R Foundation for Statistical Computing, Vienna.

Robbins, P., Polderman, A., and Birkenholz, T. 2001. Lawns and toxins: An ecology of the city. Cities 18:369-380.

Sim, S., Diesburg, K., Casler, M., and Jung, G. 2007. Mapping and comparative analysis of QTL for crown rust resistance in an Italian $\times$ perennial ryegrass population. Phytopathology 97:767-776.

Simons, M. D. 1970. Crown Rust of Oats and Grasses. The Heffernan Press, Worcester, MA.

Smiley, R. W. 1981. Nontarget effects of pesticides on turfgrasses. Plant Dis. 65:17-23.

Smiley, R. W., Dernoeden, P. H., and Clarke, B. B. 2005. Compendium of Turfgrass Diseases, 3rd ed. American Phytopathological Society, St. Paul, MN

Smith, J. D., Jackson, N., and Woolhouse, A. R. 1989. Fungal Diseases of Amenity Turf Grasses, 3rd ed. E. \& F.N. Spon, London, New York.

Stakman, E. C., Levine, M. N., Cotter, R. U., and Hines, L. 1934. Relation of barberry to the origin and persistence of physiologic forms of Puccinia graminis. J. Agric. Res. 48:953-969.

Vincelli, P. 2004. Simulations of fungicide runoff following applications for turfgrass disease control. Plant Dis. 88:391-396.

White, T. J., Bruns, T., Lee, S., and Taylor, J. 1990. Amplification and direct sequencing of fungal ribosomal RNA genes for phylogenetics. Pages 315-322 in: PCR Protocols: A Guide to Methods and Amplifications. M. A. Innis, D. H. Gelfand, J. J. Sninsky, and T. J. White, eds. Academic Press, Inc., New York. 